\title{
A study on CRM effectiveness in public and private sector banks
}

\author{
Noopur Saxena* \\ Vivekananda Institute of Professional Studies, \\ AU Block, Pitampura, Delhi 110034, India \\ Email: noopur.saxena07@yahoo.com \\ *Corresponding author
}

\section{Mayur Taneja}

Department of Commerce,

Rajdhani College,

University of Delhi

New Delhi, India

Email: mayur.taneja07@yahoo.com

\begin{abstract}
Companies have realised the importance of CRM in retaining existing customers, acquiring new customers and maximising their lifetime value. The purpose of this study is to measure the effectiveness of CRM practices in banks. To identify the antecedents which are more important to build good relationship between banks and their service users and to compare the effectiveness of CRM in public and private sector banks in Delhi. For this, the customers of private and public banks were surveyed with given 24 different statements regarding CRM practices adopted by different banks. The results of factor analyses revealed four dimensions for CRM, namely, customer experience, technology-orientation, organisational commitment and processdriven approach and reliability. This survey helps to evaluate the actual perception of service users towards CRM practices of each bank. The identification of the parameters will help bank manager to effectively implement CRM that increases customer satisfaction and loyalty.
\end{abstract}

Keywords: customer experiences; organisational commitment; customer satisfaction; process-driven approach; technology orientation; customer relationship management; public and private banks.

Reference to this paper should be made as follows: Saxena, N. and Taneja, M. (2018) 'A study on CRM effectiveness in public and private sector banks', Int. J. Public Sector Performance Management, Vol. 4, No. 1, pp.45-56.

Biographical notes: Noopur Saxena is an Assistant Professor in Vivekananda Institute of Professional Studies, GGSIPU. She holds an M.Com and B.com (H) from Delhi University. Her area of expertise is customer relationship management, banking and accounts. She has more than five years of teaching and industry experience. She has published six papers in refereed national and international journals and has co-authored a chapter in a book.

Mayur Taneja holds an M.Com and B.com $(\mathrm{H})$ from Delhi University. He is working as an Assistant Professor in Rajdhani College, University of Delhi. His area of expertise is customer relationship management, consumer behaviour 
and statistics. He has more than seven years of teaching and industry experience. He has published five papers in refereed national and international journals and has co-authored a chapter in a book.

This paper is a revised and expanded version of a paper entitled 'A study on CRM effectiveness in public and private sector banks' presented at Vivekananda International Conference VINC'17, Vivekananda Institute of Professional Studies, New Delhi, 16-17 March 2017.

\section{Introduction}

Banks play a significant role in the economy. There is remarkable transformation in the global banking environment. As a result of changing regulatory, structural and technological factors competition has been increased. Banks are adopting customer-centric strategies to enhance their relationship with existing customers in order to survive in the market. The success of a firm depends upon targeting, acquiring and retaining the right customer. The challenge is not restricted to winning a customer, but to build strong relationship and turn them into loyal customers who will generate revenue for the firm in future. According to (Kotler and Keller, 2006) marketers must connect with customers, informing, engaging and may be even energising them in the process.

In the previous years, many Indian banks have spent a lot in customer relationship management technologies to build up and nurture a long-term and mutually benefiting relationship with the customers (Uppal, 2008). There is a shift from bank centric activities to customer centric activities. The private sector banks offer much innovative strategies to attract new customer and to retain existing customers. The new technology and application including automated teller machine, phone banking, tele-banking, internet banking, etc., helped banks in managing the logistics and other activities involved in serving customers.

CRM is basically an improvement upon the data base marketing of 1980's which involve the setting up of customer service groups to speak to individual customers. The 1990's there was advancement in CRM, instead of collecting data alone, customers' services were improved and incentives, gifts, etc., was provided to loyal customers. Companies see CRM as a way to increase sales passively through active improvement of customer service supported by technology. The key to building long-term relationship with the customer is to create superior customer value and satisfaction. CRM is about magnetising, expanding and retaining profitable customers over a period of time, (Massey et al., 2001). According to Kotler and Armstrong, CRM is concerned with maintaining detailed information about every customer 'touch points' in order to maximise customer loyalty. Satisfied customers are more likely to be loyal customers and to give the company a larger share of their business. For generating employment and boosting entrepreneurial skills, focussing on CRM is a foremost requirement. This will increase self confidence among the youth of the country and will help them in becoming high achievers (Dana, 2000) 
Companies have realised the importance of CRM in retaining existing customers, acquiring new customers and maximise their lifetime value. This study is designed to measure the effectiveness of CRM practices and identify the most important parameters which are useful to build good relationship between banks and their service users and to do a comparative analysis of the effectiveness of CRM in public and private sector banks in Delhi.

\section{Literature review}

CRM is a business strategy that focuses on understanding and managing the needs of potential customers. Hair et al. (2006) defined CRM as a combination of strategic, process, organisational and technological change, which helps in better management of the company as detailed customer information is available. Kotler and Keller (2006) define CRM as the method of managing detailed information about individual customer's touch-point in order to maximise customer loyalty. By customer touch point author means any occasion on which a customer comes across a brand or product from actual experience to personal to casual observation. CRM allows companies to maintain customer database, identify the most valuable customers and provide customised products and services to increase customer loyalty. It assists in reducing the costs of serving these customers and also helps in acquiring new customers (Reichheld et al., 2002)

Padmavathy et al. (2012) developed a multi-item scale for measuring CRM effectiveness in Indian retail banks and examined its relationship with customer satisfaction, loyalty and cross-buying. The result of factor analysis shows five dimensions for CRME and found to positively affect customer satisfaction and loyalty and both customer satisfaction and loyalty-influenced cross-buying. Ramachandra and Sekar (2014) considered the core dimensions of CRM to find its impact on customer satisfaction, loyalty and cross-buying, in private sector banks in Tiruchiralpalli. The studies revealed that implementation of CRM improve business performance.

Ogbadu and Usman (2012) in his study examine the imperatives of CRM in Nigeria banking industry. The study involved survey of four selected banks with 600 respondents including customers and personnel's of selected banks. The study revealed that CRM contributed to customer loyalty and increase bank profit. So and Speece (2000) in their in-depth interviews of 42 account managers of Hong Kong commercial banks revealed that, both social and business activities were effective in building long term relationship with customers. Molin et al. (2007) in the study examine the relational benefits on customer satisfaction in retail banking. They surveyed 204 bank customers and concluded that confidence benefits have a direct, positive effect on customer satisfaction, however, special treatment benefits and social benefits did not have any significant effects on satisfaction in a retail banking environment.

Customer satisfaction is one of the important indicators of customer loyalty. Pont and McQuilken (2005) examined the relationship between satisfaction and loyalty within Australian banking industry for two distinct customer segments, retirees and university 
students. A higher satisfaction level with relationship activities was found to enhance customer loyalty for the bank. Relationship marketing facilitate better understanding of customers' need and helps in building loyal customers and also results in cost reduction, as cost of attracting and serving one new customer is more than the cost of serving one loyal customer. A firm cut the expenditure on marketing, distribution and logistics costs and thereby gain low-cost competitive advantage and service differentiation (Ndubisi, 2003 and Rosenberg and Czepiel, 1984).

Technology plays a crucial role in gaining competitive advantage through customer interaction. CRM practices enable firms to maintain customer database, so that customised offers can be made according to the tastes and preferences of individual customer. Krasnikov et al. (2009) in the study examines the impact of CRM implementation on firm cost and profit efficiency using a large sample of US commercial banks. Stochastic frontier analysis was used to estimate cost and profit efficiencies and hierarchical linear modelling was employed to measure the effect of CRM implementation on cost and profit efficiencies. They find that CRM implementation results in a decline in cost efficiency but an increase in profit efficiency.

In today's competitive environment success of a bank depends upon service quality it provides to its customers. Valmohammadi and Beladpas (2014) in their study suggested that bank should aim at improving the communication with customers, acquire information regarding the customers' needs and resolve their disputes during service failure. This will improve service quality and lead to increased profitability. Banks that communicate efficiently and reliably with customers and handle their conflicts proficiently, will build trust and quality relationship, resulting in loyal customer (Ndubisi et al., 2007).

Ogbadu and Usman (2012) in their study examine the imperatives of CRM in selected private sector banks in Nigeria. The findings shows, there exist direct relationship between CRM and banks profitability and effective CRM results in high level of customer loyalty. In order to become more customer-centric, banks have designed and implemented CRM to achieve success. Although CRM has become indispensable and important business strategy, limited research has been done to assess its effectiveness (Mithas et al., 2005; Chen et al., 2009). Thus, the present study identifies the antecedents of CRM in banking sector and compares the effectiveness of CRM in public and private sector banks.

\section{Objective}

1 To measure the effectiveness of CRM practices.

2 To identify the antecedents of CRM in banking sector.

3 To analyse and compare the factors of CRM in public and private banks respectively.

\section{Research methodology}

The population of this study is bank customers in Delhi. Non probability convenience sampling method has been used. The sample size is 166 respondents. Questionnaire is used for the purpose of data collection. The questionnaire consisted of close ended 
questions including scales. A total of 24 statements were asked and the statements were given with a likert scale ranging from 1 to 5 - from strongly disagree to strongly agree.

Table 1 Demographic information

\begin{tabular}{|c|c|c|}
\hline Items & $n$ & $\%$ \\
\hline \multicolumn{3}{|l|}{ Gender } \\
\hline Male & 101 & 60.84 \\
\hline Female & 65 & 39.16 \\
\hline \multicolumn{3}{|l|}{ Age (years) } \\
\hline Less than 20 & 47 & 28.3 \\
\hline $21-30$ & 92 & 55.4 \\
\hline $31-40$ & 18 & 10.8 \\
\hline $41-50$ & 7 & 4.2 \\
\hline More than 50 & 2 & 1.2 \\
\hline \multicolumn{3}{|l|}{ Education } \\
\hline Undergraduate & 84 & 50.6 \\
\hline Post-graduate & 48 & 28.9 \\
\hline Professional degree & 23 & 13.9 \\
\hline Others & 11 & 6.6 \\
\hline \multicolumn{3}{|l|}{ Occupation } \\
\hline Public sector & 8 & 4.8 \\
\hline Private sector & 43 & 25.9 \\
\hline Self employed & 12 & 7.2 \\
\hline Housewife & 6 & 3.6 \\
\hline Student & 88 & 53 \\
\hline Others & 9 & 5.4 \\
\hline \multicolumn{3}{|c|}{ Relationship with the bank (years) } \\
\hline Less than 1 & 21 & 12.7 \\
\hline Between 1-4 & 95 & 57.2 \\
\hline Between 4-7 & 24 & 14.5 \\
\hline Between 7-10 & 9 & 5.4 \\
\hline More than 10 & 17 & 10.2 \\
\hline
\end{tabular}

The questionnaire items were adapted from different sources. Twenty one statements were taken from (Limbad, 2016) and three statements were taken from (Padmavathy et al., 2012). The questionnaire is divided in two sections. Section A seeks to obtain responses on personal data of respondents while Section B examines the CRM practices implemented by the banks.

Both primary and secondary data were considered for the study. The primary data were collected from questionnaire and secondary data were collected from books, study materials and internet. Principal component analysis (factor analysis) is applied as a statistical tool with the help of statistical package tools for social science (SPSS V 18). 
On the basis of 166 samples (bank customers), the percentage of male and female respondents were 60.84 and 39.16 respectively, which shows the male dominancy of bank customers. In the entire sample, $28.3 \%$ of respondents fell in the age range of less than $20,55.4 \%$ in 21 to $30,10.8 \%$ in 31 to $40,4.2 \%$ in $41-50$ and $1.2 \%$ fell in the range of more than 50 . In terms of qualification, undergraduate $(50.6 \%)$, post graduate $(28.9 \%)$, professional degree (13.9\%) and others (6.6\%). Employment details reveals that $4.8 \%$ of respondents are employed in public sector, $25.9 \%$ in private sector, $7.2 \%$ are self employed, $3.6 \%$ are housewife, $53 \%$ are students and $5.4 \%$ are in other category. The years of relationship customer had with the bank: $12.7 \%$ of the respondents had less than 1 year of relationship, $57.2 \%$ of the respondents had relationship between 1-4 years, $14.5 \%$ had $4-7$ years of relationship with the bank, $5.4 \%$ had $7-10$ years of relationship with the bank and the rest $10.2 \%$ had more than ten years of relationship with the bank.

\section{Analysis and discussions}

To ascertain the adequacy of data, KMO measure of sampling adequacy is used. $\mathrm{KMO}$ is 0.910 which indicates that the sampling is adequate and responses are valid and suitable for study.

An exploratory factor analysis using Oblimin with Kaiser Normalisation was performed on the 24 items. Item-to-total correlation criterion ( $>0.4)$ was employed. Two items did not meet this criterion; however, they were retained for further analysis on the grounds of face validity. An EFA with remaining 22 items indicated a four factor solution that accounted for $66.629 \%$ of the total variance. The details of EFA have been shown in Table-2.

Table 2 Factor analysis

\begin{tabular}{|c|c|c|c|c|}
\hline Factors & $\begin{array}{l}\text { Variable } \\
\text { labels }\end{array}$ & Variable & $\begin{array}{l}\text { Factor } \\
\text { loading }\end{array}$ & $\begin{array}{l}\text { Varianc } \\
e \%\end{array}$ \\
\hline \multirow[t]{8}{*}{$\begin{array}{l}\text { F1-customer } \\
\text { experience }(\mathrm{CE})\end{array}$} & $\mathrm{V} 1$ & $\begin{array}{l}\text { Bank treats me as a very special } \\
\text { customer CE1 }\end{array}$ & .864 & 40.242 \\
\hline & $\mathrm{V} 2$ & $\begin{array}{l}\text { Bank deliver an excellent service to me } \\
\text { at any point of contact CE } 2\end{array}$ & .825 & \\
\hline & V3 & $\begin{array}{l}\text { Bank always hear my complaints and } \\
\text { resolve quickly CE3 }\end{array}$ & .767 & \\
\hline & V4 & $\begin{array}{l}\text { Bank takes my feedback seriously and } \\
\text { reply to them CE4 }\end{array}$ & .701 & \\
\hline & V5 & Bank gives me individual attention CE5 & .849 & \\
\hline & V6 & $\begin{array}{l}\text { Bank's employees are not too busy to } \\
\text { respond to me CE6 }\end{array}$ & .658 & \\
\hline & V7 & $\begin{array}{l}\text { I do not have to stand in a queue for } \\
\text { getting services CE7 }\end{array}$ & .615 & \\
\hline & V11 & Bank even answer me on call CE8 & .459 & \\
\hline \multirow[t]{3}{*}{$\begin{array}{l}\text { F2-technology } \\
\text { orientation }\end{array}$} & V22 & $\begin{array}{l}\text { Bank provide online services to reduce } \\
\text { my service costs TO1 }\end{array}$ & .862 & 10.287 \\
\hline & V23 & $\begin{array}{l}\text { Bank helps me to reduce paper works } \\
\text { TO2 }\end{array}$ & .901 & \\
\hline & V24 & $\begin{array}{l}\text { Bank uses latest technology (ATMs, } \\
\text { mobile banking and internet banking) to } \\
\text { offer quality services TO3 }\end{array}$ & .810 & \\
\hline
\end{tabular}


Table 2 Factor analysis (continued)

\begin{tabular}{|c|c|c|c|c|}
\hline Factors & $\begin{array}{l}\text { Variable } \\
\text { labels }\end{array}$ & Variable & $\begin{array}{l}\text { Factor } \\
\text { loading }\end{array}$ & $\begin{array}{l}\text { Varianc } \\
e \%\end{array}$ \\
\hline \multirow[t]{6}{*}{$\begin{array}{l}\text { F3-organisational } \\
\text { commitment }\end{array}$} & V9 & $\begin{array}{l}\text { Bank send me calendar, diary and other } \\
\text { tangible gifts OC } 1\end{array}$ & .741 & 7.374 \\
\hline & V10 & $\begin{array}{l}\text { Bank greets me anniversary, birthday } \\
\text { wishes OC2 }\end{array}$ & .699 & \\
\hline & V14 & $\begin{array}{l}\text { Bank take suggestion from me to design } \\
\text { or improve products OC } 3\end{array}$ & .719 & \\
\hline & V15 & $\begin{array}{l}\text { Bank provides customised services and } \\
\text { products to me OC4 }\end{array}$ & .528 & \\
\hline & V16 & $\begin{array}{l}\text { Bank assess customer satisfaction } \\
\text { regularly OC5 }\end{array}$ & .555 & \\
\hline & V21 & $\begin{array}{l}\text { Bank also provide me services at home } \\
\text { OC6 }\end{array}$ & .560 & \\
\hline \multirow{6}{*}{$\begin{array}{l}\text { F4-process-driven } \\
\text { approach and } \\
\text { reliability }\end{array}$} & V12 & $\begin{array}{l}\text { Bank keeps my information confidential } \\
\text { PR1 }\end{array}$ & .618 & 4.726 \\
\hline & V13 & $\begin{array}{l}\text { Bank gives me guarantees against } \\
\text { service failures PR2 }\end{array}$ & .548 & \\
\hline & V18 & $\begin{array}{l}\text { Bank give me a call in case if deficit in } \\
\text { my account before clearing the cheques } \\
\text { PR3 }\end{array}$ & .719 & \\
\hline & V19 & $\begin{array}{l}\text { Continuously maintains, updates and } \\
\text { monitors my account information PR } 4\end{array}$ & .600 & \\
\hline & V20 & $\begin{array}{l}\text { Bank provides value-added information } \\
\text { along with its products/services PR } 5\end{array}$ & .445 & \\
\hline & & Total & & 62.629 \\
\hline
\end{tabular}

The first factor 'customer experience' explains $40.242 \%$ of the total variance. This factor depicts how well banks conform to CRM efforts by quickly attending the customers complaints and problems and efficiently solving it through proactive customer support. The bank gives individual attention and treats them as a special customer. This increases customer satisfaction and ensures their needs are fulfilled on a continual basis.

The second factor 'technology orientation' explains $10.287 \%$ of the total variance. This describes the latest technologies used by banks like ATMs, mobile banking and internet banking to offer quality services. CRM technology enables the banks to collect customer information at various points of contact and thereby provide customised products and services to maximise customer value.

The third factor 'organisational commitment' explains $7.374 \%$ of the total variance and shows the endeavour taken by banks and its employees to serve their customers efficiently. It shows bank's values and principles towards customer orientation. It is essential for the firm to understand the importance of implementing CRM in order to build long-term and mutually benefitting relationships with their customers. (Yim et al., 2004)

The fourth factor 'process-driven approach and reliability' explains $4.726 \%$ of the total variance. This dimension facilitates the banks to fulfil customer requests with speed and shrewdness and shows the degree to which banks have delivered the services to its customers as promised. 
Table 3 Result of factor analysis of public banks

\begin{tabular}{|c|c|c|c|c|}
\hline Factors & $\begin{array}{l}\text { Variable } \\
\text { labels }\end{array}$ & Variable & $\begin{array}{l}\text { Factor } \\
\text { loading }\end{array}$ & $\begin{array}{l}\text { Variance } \\
\quad \%\end{array}$ \\
\hline \multirow{8}{*}{$\begin{array}{l}\text { F1-process-driven } \\
\text { approach and } \\
\text { reliability }\end{array}$} & $\mathrm{V} 12$ & Bank keeps my information confidential PR1. & .527 & 41.923 \\
\hline & V13 & $\begin{array}{l}\text { Bank gives me guarantees against service } \\
\text { failures PR2. }\end{array}$ & .459 & \\
\hline & V16 & $\begin{array}{l}\text { Bank assess customer satisfaction regularly } \\
\text { PR3. }\end{array}$ & .590 & \\
\hline & V17 & $\begin{array}{l}\text { Bank gives SMS/Call alerts for new offers } \\
\text { PR4. }\end{array}$ & .793 & \\
\hline & V18 & $\begin{array}{l}\text { Bank give me a call in case if deficit in my } \\
\text { account before clearing the cheques PR5. }\end{array}$ & .718 & \\
\hline & V19 & $\begin{array}{l}\text { Continuously maintains, updates and } \\
\text { monitors my account information PR6. }\end{array}$ & .709 & \\
\hline & V20 & $\begin{array}{l}\text { Bank provides value-added information along } \\
\text { with its products/services PR } 7 \text {. }\end{array}$ & .813 & \\
\hline & V21 & Bank also provide me services at home PR8. & .421 & \\
\hline \multirow[t]{3}{*}{$\begin{array}{l}\text { F2-technology } \\
\text { orientation }\end{array}$} & V22 & $\begin{array}{l}\text { Bank provide online services to reduce my } \\
\text { service costs TO1. }\end{array}$ & .808 & 11.844 \\
\hline & V23 & Bank helps me to reduce paper works TO2. & .887 & \\
\hline & V24 & $\begin{array}{l}\text { Bank uses latest technology (ATMs, mobile } \\
\text { banking and internet banking) to offer quality } \\
\text { services TO3. }\end{array}$ & .821 & \\
\hline \multirow[t]{3}{*}{$\begin{array}{l}\text { F3-organisational } \\
\text { commitment }\end{array}$} & V9 & $\begin{array}{l}\text { Bank send me calendar, diary and other } \\
\text { tangible gifts OC1. }\end{array}$ & .772 & 7.265 \\
\hline & V10 & $\begin{array}{l}\text { Bank greets me anniversary, birthday wishes } \\
\text { OC2. }\end{array}$ & .852 & \\
\hline & V14 & $\begin{array}{l}\text { Bank take suggestion from me to design or } \\
\text { improve products OC } 3 \text {. }\end{array}$ & .466 & \\
\hline \multirow[t]{5}{*}{$\begin{array}{l}\text { F4-customer } \\
\text { experience (CE) }\end{array}$} & V1 & $\begin{array}{l}\text { Bank treats me as a very special customer } \\
\text { CE1. }\end{array}$ & .819 & 5.256 \\
\hline & $\mathrm{V} 2$ & $\begin{array}{l}\text { Bank deliver an excellent service to me at } \\
\text { any point of contact CE2. }\end{array}$ & .764 & \\
\hline & V3 & $\begin{array}{l}\text { Bank always hear my complaints and resolve } \\
\text { quickly CE3. }\end{array}$ & .774 & \\
\hline & V4 & $\begin{array}{l}\text { Bank takes my feedback seriously and reply } \\
\text { to them CE4. }\end{array}$ & .737 & \\
\hline & V5 & Bank gives me individual attention CE5. & .871 & \\
\hline \multirow[t]{4}{*}{$\begin{array}{l}\text { F4-customer } \\
\text { experience (CE) }\end{array}$} & V6 & $\begin{array}{l}\text { Bank's employees are not too busy to } \\
\text { respond to me CE6. }\end{array}$ & .652 & \\
\hline & V7 & $\begin{array}{l}\text { I do not have to stand in a queue for getting } \\
\text { services CE7. }\end{array}$ & .674 & \\
\hline & V8 & $\begin{array}{l}\text { Bank's higher authority also gives me } \\
\text { response. }\end{array}$ & .479 & \\
\hline & V11 & $\begin{array}{l}\text { Bank even answer me on call CE8. } \\
\text { Total }\end{array}$ & .449 & 66.288 \\
\hline
\end{tabular}


Table 4 Result of factor analysis of private banks

\begin{tabular}{|c|c|c|c|c|}
\hline Factors & $\begin{array}{l}\text { Variable } \\
\text { labels }\end{array}$ & Variable & $\begin{array}{l}\text { Factor } \\
\text { loading }\end{array}$ & $\begin{array}{l}\text { Variance } \\
\%\end{array}$ \\
\hline \multirow[t]{8}{*}{$\begin{array}{l}\text { F1-organisational } \\
\text { commitment }\end{array}$} & V9 & $\begin{array}{l}\text { Bank send me calendar, diary and other } \\
\text { tangible gifts OC } 1 \text {. }\end{array}$ & .757 & 51.253 \\
\hline & V10 & $\begin{array}{l}\text { Bank greets me anniversary, birthday } \\
\text { wishes OC } 2 \text {. }\end{array}$ & .538 & \\
\hline & V11 & Bank even answer me on call OC3 & .513 & \\
\hline & V13 & $\begin{array}{l}\text { Bank gives me guarantees against service } \\
\text { failures OC } 4 \text {. }\end{array}$ & .815 & \\
\hline & V14 & $\begin{array}{l}\text { Bank take suggestion from me to design or } \\
\text { improve products OC } 5 \text {. }\end{array}$ & .720 & \\
\hline & V15 & $\begin{array}{l}\text { Bank provides customised services and } \\
\text { products to me OC6. }\end{array}$ & .747 & \\
\hline & V16 & $\begin{array}{l}\text { Bank assess customer satisfaction } \\
\text { regularly OC } 7 .\end{array}$ & .728 & \\
\hline & V21 & $\begin{array}{l}\text { Bank also provide me services at home } \\
\text { OC8. }\end{array}$ & .429 & \\
\hline \multirow{8}{*}{$\begin{array}{l}\text { F2-technology } \\
\text { orientation and } \\
\text { process-driven } \\
\text { approach and } \\
\text { reliability }\end{array}$} & V8 & $\begin{array}{l}\text { Bank's higher authority also gives me } \\
\text { response TP1. }\end{array}$ & -.430 & 10.822 \\
\hline & V12 & $\begin{array}{l}\text { Bank keeps my information confidential } \\
\text { TP2. }\end{array}$ & -.625 & \\
\hline & V17 & $\begin{array}{l}\text { Bank gives SMS/Call alerts for new offers } \\
\text { TP3. }\end{array}$ & -.625 & \\
\hline & V19 & $\begin{array}{l}\text { Continuously maintains, updates and } \\
\text { monitors my account information TP4. }\end{array}$ & -.644 & \\
\hline & V20 & $\begin{array}{l}\text { Bank provides value-added information } \\
\text { along with its products/services TP5. }\end{array}$ & -.653 & \\
\hline & V22 & $\begin{array}{l}\text { Bank provide online services to reduce my } \\
\text { service costs TP6g. }\end{array}$ & -.956 & \\
\hline & V23 & Bank helps me to reduce paper works TP7. & -.916 & \\
\hline & V24 & $\begin{array}{l}\text { Bank uses latest technology (ATMs, } \\
\text { mobile banking and internet banking) to } \\
\text { offer quality services TP8. }\end{array}$ & -.796 & \\
\hline \multirow[t]{7}{*}{$\begin{array}{l}\text { F3-customer } \\
\text { experience (CE) }\end{array}$} & V1 & $\begin{array}{l}\text { Bank treats me as a very special customer } \\
\text { CE1. }\end{array}$ & .884 & 4.718 \\
\hline & $\mathrm{V} 2$ & $\begin{array}{l}\text { Bank deliver an excellent service to me at } \\
\text { any point of contact CE2. }\end{array}$ & .770 & \\
\hline & V3 & $\begin{array}{l}\text { Bank always hear my complaints and } \\
\text { resolve quickly CE3. }\end{array}$ & .470 & \\
\hline & V5 & Bank gives me individual attention CE4. & .717 & \\
\hline & V6 & $\begin{array}{l}\text { Bank's employees are not too busy to } \\
\text { respond to me CE5. }\end{array}$ & .653 & \\
\hline & V7 & $\begin{array}{l}\text { I do not have to stand in a queue for } \\
\text { getting services CE6. }\end{array}$ & .635 & \\
\hline & & Total & & 66.793 \\
\hline
\end{tabular}


Table 5 Comparison of public and private sector banks

\begin{tabular}{|c|c|c|c|}
\hline \multicolumn{2}{|c|}{ Public banks } & \multicolumn{2}{|c|}{ Private banks } \\
\hline Factors & $\begin{array}{l}\% \text { of variance } \\
\text { explained }\end{array}$ & Factors & $\begin{array}{l}\text { \% of variance } \\
\text { explained }\end{array}$ \\
\hline $\begin{array}{l}\text { F1-process-driven } \\
\text { approach and } \\
\text { reliability }\end{array}$ & 41.923 & $\begin{array}{l}\text { F1-organisational } \\
\text { commitment }\end{array}$ & 51.253 \\
\hline $\begin{array}{l}\text { F2-technology } \\
\text { orientation }\end{array}$ & 11.844 & $\begin{array}{l}\text { F2-technology orientation } \\
\text { and process-driven } \\
\text { approach and reliability }\end{array}$ & 10.822 \\
\hline $\begin{array}{l}\text { F3-organisational } \\
\text { commitment }\end{array}$ & 7.265 & $\begin{array}{l}\text { F3-customer experience } \\
\text { (CE) }\end{array}$ & 4.718 \\
\hline $\begin{array}{l}\text { F4-customer } \\
\text { experience (CE) }\end{array}$ & 5.256 & & \\
\hline Total & 66.288 & & 66.793 \\
\hline
\end{tabular}

Tables 3 and 4 shows the result of factor analysis in public and private sector banks respectively, to identify which factors is more important in public banks and which is considered more important in private banks.

The findings show that in case of public banks, process-driven approach and reliability explains $41.923 \%$ of the total variance and is considered the most important factor. The second factor technology orientation explains $11.844 \%$ of the total variance. $7.265 \%$ of the total variance is explained by third factor which is organisational commitment and only $5.256 \%$ of the total variance is explained by customer experience.

In case of private sector bank the first factor is organisational commitment which explains $51.253 \%$ of the total variance, technology orientation and process-driven approach and reliability emerged as a single factor and explains $10.822 \%$ of the total variance, $4.718 \%$ of the total variance is explained by customer experience.

The findings show that more number of people has accounts in public sector banks. People prefer to go to public banks because they consider it more reliable and process oriented. The major trust factor in public banks is transparency of interest rate policies. The customer receives value-added information, SMS/call alerts for new offers, guarantees against service failures, etc.

Customers like private sector banks because of their organisational commitment. They provide customised products and services, assess customer satisfaction regularly, takes suggestions for improvement, provide services at home, friendly behaviour of the staff as well as quick and fast services that is being provided.

As far as technology orientation is concerned - reduction of paper work, use of latest technology (ATMs, mobile banking and internet banking) and provision of online services to reduce service costs, the customers of both public and private sector banks are satisfied.

\section{Implications and conclusions}

The findings of this study have significant implication for bank managers. In order to enhance the business performance, the identified key dimensions of CRM namely, customer experience, technology orientation, organisational commitment and process 
driven approach and reliability should be implemented. Further, the comparison among customer's opinion for public and private sector banks has identified the strong and weak areas of both Public and Private sector banks.

The factors which emerged more important in public sector banks are process-driven approach and reliability, the banks communicate timely and reliable information regarding new offers, guarantees against service failures and the customer is well informed about the action taken by the bank in case any problem arises to the customer. The second factor is technology orientation; next one is organisational commitment and finally customer experience. Thus it can be said that public sector banks are preferred because people consider it as more reliable and process oriented. But the public banks needs to improve in terms of providing customer experiences.

In case of private sector banks, their strength is organisational commitment. Customers prefer private sector banks because of the availability of customised products and services, they are flexible in serving the customers, banks take their suggestions for improvement, assess customer satisfaction regularly, provide services at home, friendly behaviour of the staff as well as quick and fast services that is being provided. But they also needs to improve upon providing better customer experiences like reduced waiting time, making the customer feel special, hear their complaints and take action to resolve it quickly. This will help the managers and decision makers to take requisite steps for effective implementation of CRM practices, resulting in more satisfied and profitable customers.

\section{Limitation}

The limitations of this study are: firstly, from the sample features (i.e., convenience sample) one cannot draw concrete conclusions as the data is not representative of the entire population. Secondly, other factors can also be studied like trust, relationship quality, etc. Thirdly, the survey was done only in the Delhi region; future survey can be done in wider geographical area with more respondents.

\section{Future research}

This study examines customer perceptions towards CRM; future study can investigate employee perceptions towards CRM and its impact on business performance. Secondly, the study focuses on banks only, future research can replicate this study in other sectors also like education, tourism, hospitality, etc. Thirdly, the same research can be done on selected banks which will help to compare the performance of one bank with the other. Fourthly, the study focuses on customer satisfaction only; future study can also study other factors like trust, relationship quality, etc.

\section{References}

Chen, J-S., Yen, H.R., Li, E. and Ching, R.K. (2009) 'Measuring CRM effectiveness: construct development, validation and application of a process-oriented model', Total Quality Management and Business Excellence, Vol. 20, No. 3, pp.283-299. 
Dana, L.P. (2000) 'Creating entrepreneurs in India', Journal of Small Business Management, pp.86-91, January.

Hair, J.F., Black, B., Babin, B., Anderson, R.E. and Tatham, R.L. (2006) Multivariate Data Analysis, 6th ed., Pearson Prentice Hall, Englewood Cliffs, NJ.

Kotler, P. and Keller, K.L. (2006) Marketing Management, 12th ed., Pearson Prentice Hall, Upper Saddle River New Jersey, USA.

Krasnikov, A., Jayachandran, S. and Kumar, V. (2009) 'The impact of customer relationship management implentation on cost and profit efficiencies: evidence from the US commercial banking industry', Journal of Marketing, Vol. 73, No. 6, pp.61-76.

Limbad, S.J. (2016) 'Measuring performance on customer relationship management practices of public sector banks in Surat city', International Journal of Research in Business Management, Vol. 4, No. 2, pp.51-58.

Massey, A.P., Montoya-Weiss, M.M. and Holcom, K. (2001) 'Re-engineering the customer relationship: leveraging knowledge assets at IBM', Decision Support Systems, Vol. 32, No. 2, pp.155-170.

Mithas, S., Krishnan, M. and Fornell, C. (2005) 'Why do customer relationship management applications affect customer satisfaction?', Journal of Marketing, Vol. 20, No. 3, pp.201-209.

Molin, A., Martin-Consuegr, D. and Esteban, A. (2007) 'Relational benefits and customer satisfaction in retail banking', International Journal of Bank Marketing, Vol. 25, No. 4, pp.253-271.

Ndubisi, N.O. (2003) 'Service quality: understanding customer perception and reaction and its impact on business', International Journal of Business, Vol. 5, No. 2, pp.207-219.

Ndubisi, N.O., Wah, C.K. and Ndubisi, G.C. (2007) 'Supplier-customer relationship management and customer loyalty the banking industry perspective', Journal of Enterprise Information Management, Vol. 20, No. 2, pp.222-236.

Ogbadu, D.E. and Usman, A. (2012) 'Imperatives of customer relationship management in Nigeria banking industry', Kuwait Chapter of Arabian Journal of Business and Management Review, Vol. 2, No. 1, pp.59-72.

Padmavathy, C., Balaj, M. and Sivakumar, V. (2012) 'Measuring effectiveness of customer relationship management in Indian retail banks', International Journal of Bank Marketing, Vol. 30, No. 4, pp.246-266.

Pont, M. and McQuilken, L. (2005) 'An empirical investigation of customer satisfaction and loyalty across two divergent bank segments', Journal of Financial Services Marketing, Vol. 9, No. 4, pp.344-359.

Ramachandra, R. and Sekar, D.S. (2014) 'A study on customer relationship management (CRM) effectiveness in private banks, Tiruchirappalli', International Journal of Management, Vol. 5, No. 12, pp.12-23.

Reichheld, F.F., Sasser, P. and Rigby, D.K. (2000) 'Avoid the four perils of CRM', Harvard Business Review, July-August, pp.1-9.

Rosenberg, L.J. and Czepiel, J.A. (1984) 'A marketing approach for consumer retention', Journal of Consumer Marketing, Vol. 1, No. 2, pp.45-51.

So, S.L. and Speece, M.W. (2000) 'Perceptions of relationship marketing among account managers of commercial banks in a Chinese environment', International Journal of Bank Marketing, Vol. 18, No. 7, pp.315-27.

Uppal, R.K. (2008) Customer Relationship Management in Indian Banking Industry, New Century Publications, New Delhi.

Valmohammadi, C. and Beladpas, M. (2014) 'Customer relationship management and service quality, a survey within the banking sector', Industrial and Commercial Training, Vol. 46, No. 2, pp.77-83.

Yim, F.H-K., Anderson, R.E. and Swaminathan, S. (2004) 'Customer relationship management: its dimensions and effect on customer outcomes', The Journal of Personal Selling and Sales Management, Vol. 24, No. 4, pp.263-278. 